Trinity University

Digital Commons @ Trinity

Classical Studies Faculty Research

Classical Studies Department

Winter 2007

\title{
Walking with Odysseus: The Portico Frame of the Odyssey Landscapes
}

Timothy M. O'Sullivan

Trinity University, tosulliv@trinity.edu

Follow this and additional works at: https://digitalcommons.trinity.edu/class_faculty

Part of the Classics Commons

\section{Repository Citation}

O'Sullivan, T.M. (2007). Walking with Odysseus: The portico frame of the Odyssey landscapes. American Journal of Philology, 128(4), 497-532. doi:10.1353/ajp.2008.0007

This Article is brought to you for free and open access by the Classical Studies Department at Digital Commons @ Trinity. It has been accepted for inclusion in Classical Studies Faculty Research by an authorized administrator of Digital Commons @ Trinity. For more information, please contact jcostanz@trinity.edu. 


\title{
WALKING WITH ODYSSEUS: THE PORTICO FRAME OF THE ODYSSEY LANDSCAPES
}

\author{
TIMOTHY M. O'SULLIVAN
}

\begin{abstract}
$\sim$
Abstract. This article examines the cultural and artistic context of one of the most famous Roman frescoes, the Odyssey Landscapes. It argues that the painting's fictive portico frame would have evoked in the Roman viewer the experience of the ambulatio, the act of walking for leisure and contemplation that came to be an essential element of a properly Hellenized otium. The painted portico thus puts the viewers in the proper frame of mind to appreciate the intellectual associations of the painting as they walk with Odysseus on a parallel journey of philosophical reflection.
\end{abstract}

Media vero spatia, quae erunt subdiu inter porticus, adornanda viridibus videntur, quod hypaethroe ambulationes habent magnam salubritatem. et primum oculorum, quod ex viridibus subtilis et extenuatus aer propter motionem corporis influens perlimat speciem et ita auferens ex oculis umorem crassum, aciem tenuem et acutam speciem relinquit; praeterea, cum corpus motionibus in ambulatione calescat, umores ex membris aer exsugendo inminuit plenitates extenuatque dissipando quod plus inest quam corpus potest sustinere.

(Vitruvius De architectura 5.9.5)

The spaces in the middle, between the porticoes and open to the sky, should be decorated with greenery, since walks in the open air bring great health benefits. First of all, because of the movement of the body, the fine and rarefied air from the greenery flows into the eyes and sharpens the sight; in so doing it removes the heavy moisture from the eyes and leaves behind clear vision and sharp sight. Moreover, since the body heats up with movement during a walk, the air reduces saturation by sucking moisture out of the limbs, and thins them out by dissipating whatever is more than the body can sustain. ${ }^{1}$

${ }^{1}$ Except where noted, all translations are my own. 
WE DO NOT KNOW HOW MANY OF VITRUVIUS' CONTEMPORARIES would have characterized the benefits of walking with such scientific precision, but we can be sure of the popularity of walking as a leisure activity in late republican and early imperial Rome. One sign of that popularity is the sheer number of ambulatory spaces that decorated the ancient city, particularly the many public porticoes constructed from the second century B.C.E. onwards. ${ }^{2}$ These porticoes were multifunctional, but their appeal was in part due to the fact that they gave the Roman people a taste of the aristocratic lifestyle; as they strolled in a beautiful setting full of works of art and elaborate landscaping, they enjoyed precisely the experience that wealthy Romans of the late republic cultivated in their villas and urban mansions. ${ }^{3}$ In the Roman domestic setting, the leisurely stroll had a decidedly intellectual flavor, exercising both body and mind. ${ }^{4}$ The intellectual associations of ambulatory spaces in the villa even inspired Roman aristocrats to name parts of the property for famous monuments around the empire and decorate them accordingly;

2Vitruvius' commendation of walking, for example, appears in his section on theater colonnades, which he surely wrote with the portico of Pompey in mind. On the Roman public portico, see Richardson 1992, s.v. "Porticus"; Senseney 2002. See also Velleius Paterculus, who begins his second book with the familiar topos of Roman decline in the second century B.C.E. and uses the importation of public porticoes as a symbol of that decline (2.1.1-2): "in somnum a vigiliis, ab armis ad voluptates, a negotiis in otium conversa civitas. tum Scipio Nasica in Capitolio porticus, tum quas praediximus Metellus, tum in circo Cn. Octavius multo amoenissimam moliti sunt, publicamque magnificentiam secuta privata luxuria est" "Vigilance turned to slumber, weapons turned to pleasures, business became leisure: our society was turned upside-down. It was then that Scipio Nasica built porticoes on the Capitoline, and Metellus built the porticoes we mentioned above; it was then that Gnaeus Octavius built a portico that was the fanciest by far, and private luxury followed public splendor").

${ }^{3}$ In addition to the Velleius quote above, the connection between public porticoes and private leisure is made most explicit by Augustus' decision to replace the vast domus of Vedius Pollio, bequeathed to the emperor, with the Portico of Livia; Ovid attests to the didactic value of the portico (Fast. 6.639-40, 647-48): "disce tamen, veniens aetas: ubi Livia nunc est / porticus, immensae tecta fuere domus. / . . sic agitur censura et sic exempla parantur, / cum iudex, alios quod monet, ipse facit" ("But know this, future ages: where Livia's portico now stands were once the buildings of an enormous house .... This is how a censor acts, this is how to set an example, when the authority himself carries out the advice he has imparted to others"). Similarly, MacDonald and Pinto 1995, 54, suggest that "the colonnaded paths leading from one building or vantage point to another" at Hadrian's Villa are "the Villa equivalents of urban porticoes."

${ }^{4}$ Cf. Pliny's comment on Spurinna's rigorous life of leisure (Ep.3.1.4): “ambulat milia passuum tria nec minus animum quam corpus exercet" ("He walks three thousand paces, and exercises his mind no less than his body"). 
the educational benefits of travel abroad were imported to the private setting, and a walk through one's own philosophical playground became, in effect, a kind of metaphorical tourism. ${ }^{5}$

My aim in this article is to show how an awareness of the particular power of this cultural metaphor-walking as a sign of intellectual leisure-can alter our perception of one of the most studied artifacts from antiquity: the Roman fresco known as the Odyssey Landscapes (plates 1-2; figs. 1-3). ${ }^{6}$ Unlike contemporary paintings of the mid-first century B.C.E., in which either figural or architectural subjects dominate, the fresco is famous for its emphasis on natural forms; rocks, cliffs, crags, bays, caves, trees, islands, and ocean all compete for the viewer's attention. ${ }^{7}$ In the midst of this dramatic natural setting are miniature figures enacting scenes from the Homeric Odyssey: specifically, from that part of the Odyssey narrated by Odysseus himself, including his encounter with the Laestrygonians and with Circe, the nekuia, and the voyage past the Sirens.

The mural's modern designation as the "Odyssey Landscapes" perfectly captures the interplay of myth and nature that is its most famous feature; in addition to the human figures and the natural setting, however, the wall decoration has a third element, a fact that is sometimes overlooked both in scholarship and in reproductions of the work. Framing the landscape is a series of painted red pillars, evenly spaced, creating the illusion that the viewer must look through a colonnade in order to see

${ }^{5}$ Cicero's Tusculan Academy (e.g., Att. 1.4.3) is the most famous example of this trend; see Neudecker 1988,11-14. On the practice of naming parts of the villa for foreign places and monuments, see Görler 1990. On metaphorical tourism in the Roman villa, see Bergmann 2001 and O'Sullivan 2006. The connection between walking and traveling is also seen in the metaphorical use of perambulare to mean "to travel"; see TLL 10.1.1185.66-72, 1186.23-48 (Schmitz).

${ }^{6}$ The painting is currently housed in the Sala delle Nozze Aldobrandine at the Vatican, save for a fragmentary panel (fig. 3) in the Palazzo Massimo. The bibliography on the painting is vast. Biering 1995 is the most complete treatment; von Blanckenhagen 1963 is still a useful overview, although his central thesis - that the painting is a copy of a Hellenistic original—is not universally accepted (further discussion below). Coarelli (1998) has more recently provided a thorough reassessment of the painting's original setting.

${ }^{7}$ The dating is newly controversial thanks to Biering $1995,181-90$, who argues on stylistic grounds that the fresco should be dated to the last decade of the first century B.C.E. At least two scholars have already rejected the new date, however: see Coarelli 1998, 26-30, and Tybout 2001,35-36. Coarelli's argument is largely based on the fact that fragments of a pre-Julian fasti were discovered at the site, though it is not clear why the landscapes and the fasti were necessarily painted at the same time. 
the mythical landscape "beyond" it (fig. 4). ${ }^{8}$ These pillars serve to divide the frieze into individual units more conducive for viewing. By its very compositional technique, the mural encourages the viewer to look past this architectural frame; yet to do so ignores the fact that these pillars are as much a representation as the landscape "behind" them, and are therefore as worthy of interpretation as the rest of the painting.

In what follows, I argue that the portico frame of the Odyssey Landscapes serves not only a narrative function but also an interpretive one; the portico would have evoked in the Roman viewer the experience of the ambulatio, the act of walking for leisure and contemplation that came to be an essential element of a properly Hellenized otium. The aristocratic stroll was an advertisement of intellectual refinement, and it even became an embodied performance of the mental theoria espoused by Plato and his followers as the model for philosophical inquiry. ${ }^{9}$ As a result, the painted portico puts the viewers in the proper frame of mind to appreciate the intellectual associations of the Odyssey Landscapes as they walk with Odysseus on a parallel journey to greater insight.

\section{THE ODYSSEY LANDSCAPES: AN OVERVIEW}

The Odyssey Landscapes were hailed as a landmark of Greco-Roman art immediately upon their discovery in Rome in $1848 .^{10}$ The construction of low-income housing along the Via Graziosa on the Esquiline came to a standstill when workers discovered a segment of opus reticulatum; subsequent exploration revealed panels 2 and 3 of the Odyssey Landscapes (plate 1). ${ }^{11}$ Excavation of the rest of the fresco was then interrupted by

${ }^{8}$ Throughout this article I will use the term "pillar" for the painted architectural supports, since they are rectangular in cross-section. In so doing, I follow the terminology suggested by Ginouvès 1992, 63, who reserves "pillar" for independent supports which are square or rectangular in cross-section, and "pier" for massive or irregular supports; in practice, however, the two terms are often reversed, as he himself notes.

${ }^{9}$ On the history of the metaphorical appropriation of theoria by Greek philosophers, see Nightingale 2004. For the connection between the Roman ambulatio and philosophical theoria, see O'Sullivan 2006.

${ }^{10}$ Braun's excitement is typical $(1849,27)$ : "Zwischen [den Pilastern] aber entfalten sich landschaftliche Scenen von einer Großartigkeit und Originalität des Vortrags, wie er kaum sonst wo vorkommt."

${ }^{11}$ Although technically inaccurate, "panel" is still a useful way to refer to the individual scenes that appear between the pillars of the painted portico. The first panel was already destroyed when the painting was discovered and left in situ, so by convention the first extant panel (the initial encounter between Odysseus' men and the Laestrygonian 
disputes both large and small: that year, the city was paralyzed by civil unrest that led to the short-lived repubblica romana (1848-49), while on the Via Graziosa, Sig. Filippo Bennicelli, who owned the house under which the remaining panels of the Odyssey Landscapes continued, managed to hold up excavation by demanding more money from the state. ${ }^{12}$ Emil Braun, secretary of the Deutsches Archäologisches Institut in Rome, lamented the fact that a painting of such importance was left to languish in the elements for almost a year, but further damage was inflicted by the archeologists themselves, who ordered restorations of the fresco during and after its excavation. ${ }^{13}$

A summary of the original circumstances of the excavation is important, since the findspot was buried, along with the Via Graziosa itself, by the construction of the Via Cavour in the 1880s. Moreover, any original excavation reports have been lost, and we are left with the rather unsystematic account of Pietro Matranga, a Hellenist at the Vatican library who wrote the first monograph on the painting. ${ }^{14}$ Our knowledge of the original context of the work is therefore somewhat limited. We cannot be sure, for example, what type of room the fresco decorated (atrium, peristyle, and cryptoporticus have all been suggested), nor do we know for certain whether or not the excavated building was a domus at all, though this is usually assumed. Matranga actually argued that the structure was the Portico of Livia $(1852,103-37)$, but the location of the portico on the marble plan does not support his thesis. More recently, Kuttner $(2003,112)$ has pointed out that the paintings were discovered in an area that boasted numerous suburban horti, while Coarelli 1998 insists that the paintings

princess; see plate 1) is referred to as the second (as in von Blanckenhagen 1963 and Biering 1995, among others).

${ }^{12}$ See Henzen 1850, 167: "Der Besitzer, Herr Bennicelli, ist mit der Alterthumscommission in Streit über den ihm zu bewilligenden Preis, und mittlerweile bleiben die Gemälde in ihrem dunklen Stollen allen Zufälligkeiten ausgesetzt." For an overview of the available evidence for the discovery and excavation of the Odyssey Landscapes, see Biering 1995 167-80, 195-96.

${ }^{13}$ The most damaging restoration was the application of a fixative that altered the original colors; a second round of restorations in 1952-56 removed the fixative but also some of the original painting in panels 4 and 5. See Biering 1995, 14-19.

${ }^{14}$ Matranga 1852 . The bulk of the monograph is only tangentially related to the painting: the first chapter (pp. 1-53) uses the landscape paintings to argue that the Laestrygonians inhabited the area around modern Terracina, ca. $90 \mathrm{~km} \mathrm{SE}$ of Rome, while the second chapter (pp. 55-100) proposes that Od. 7.104 refers to the carding of wool and not to the grinding of grain. The two appendices (pp. 103-48) focus more specifically on the painting and the details of its discovery and excavation. 
decorated a grand domus and that the front entryway and atrium of this house are identifiable on the marble plan. The fragment of the marble plan breaks off well before the site of the 1849 excavation, however, and the domus in question is not on the same axis as the Odyssey Landscapes wall, so Coarelli's identification is hardly conclusive. ${ }^{15}$

Similarly, there is some confusion in the scholarship about the placement of the frieze on the wall itself. Most accounts claim that the frieze was situated high on the wall, though as Biering (1995, 169-70) has convincingly argued, the notion that we have an exact measurement is based on a misreading. Matranga $(1852,112, n .12)$ gives a measurement from the floor to the beginning of a vault (5.5 meters), which some have used (see, e.g., Coarelli 1998, 31) to place the bottom of the frieze about 4 meters high. But, as Biering points out, there is no suggestion in Vespignani's drawings that the ancient floor was excavated, nor is there any indication of a vaulted ceiling; Biering argues that Matranga has misidentified as a vault the beginning of an arch much higher on the wall and that the measurement reflects the depth of the excavation, not the height of the paintings. Still, the open vista on the upper part of the wall is a relatively common feature of the second style, and it is reasonable to assume that the frieze was somewhere above eye level. ${ }^{16}$

The incomplete state of our knowledge has even been exaggerated by scholars: there has been some debate, for example, over whether or not the frieze would have continued on more than the one excavated wall, even though Matranga explicitly states that there were panels on the preceding wall that were left unexcavated because they were in such a state of disrepair (fig. 5). ${ }^{17}$ Nonetheless, we still do not know what per-

${ }^{15}$ Moreover, as one of the readers for $A J P$ correctly points out, there is still no reason to rule out the possibility that the painting decorated a public building. In this article, I follow the scholarly consensus by assuming that the painting was part of a domestic ensemble, but my argument that the painted portico evokes the idea of walking, and its many intellectual associations in late republican Rome, could apply just as easily to public or private decoration. $39-57$.

${ }^{16}$ For the open upper part as a feature of the second style, see Engemann 1967,

${ }^{17}$ Matranga 1852, 109. One of Vespignani’s drawings (Matranga 1852, Table 10; see fig. 5) clearly shows the outline of the portico frame on the wall at right angles to the wall with the Odyssey Landscapes. Andreae has argued in a number of publications (e.g., 1962, 108; 1988, 282) that the first panel must have depicted the Polyphemus episode, on the grounds that it could not have been omitted; since, however, there was another frieze preceding the destroyed panel, the argument does not hold. Biering 1995, 172-74, has tentatively suggested that the fragmentary Sirens panel (fig. 3) was originally on a third wall, at right angles to the extant frieze. 
centage of the original frieze we possess or what the wall looked like beneath the landscapes. Yet the central scholarly controversy surrounding the work centers not on any of these unknowns but on the one aspect of the painting that would seem to be beyond dispute: despite the fact that the Odyssey Landscapes are one of the relatively few examples of ancient wall painting unearthed in the city of Rome itself, scholars have questioned whether the work is really "Roman." Peter von Blanckenhagen argued at great length in an article of 1963 that the fresco was a copy of a now-lost Hellenistic original, and the painting has long enjoyed a kind of dual citizenship, serving as a dependable highlight in handbooks on both Roman and Hellenistic art. ${ }^{18}$ The temptation to treat the mural as evidence of an elaborate (but almost entirely lost) tradition of Hellenistic landscape painting has been too much for many scholars to resist. For one thing, much of Roman wall painting, particularly that of the First and Second Style, has direct or indirect antecedents in Greek painting. ${ }^{19}$ Furthermore, the development of the bucolic genre by Hellenistic poets such as Theocritus and Moschus cries out for the visual analog that a tradition of Hellenistic landscape painting would provide. ${ }^{20}$ The discovery of the frieze of the hunt on the so-called tomb of Philip at Vergina in 1977 has

${ }^{18}$ Von Blanckenhagen 1963 was not the first to make this general point, though his is the most complete development of the argument. His article, in addition to being an excellent overview of the painting and its problems, also has a superb summary of the scholarship on the disputed origin of the painting. For a prominent placement of the painting in a work on Hellenistic art, see Pollitt 1986, 185-209, esp. 185-86, and 208-9, though ironically his is among the most balanced treatments of its origin and one to which I am quite sympathetic: "To relegate the Odyssey landscapes to the status of copies of some hypothetical Greek work of the second century B.C. when all the extant evidence suggests that no such work existed is perverse. On the other hand to deny that the Odyssey paintings represent the natural culmination of a developing tradition of Hellenistic landscape painting seems obtuse. They brought Hellenistic technique into a world increasingly dominated by Roman taste and are a product of the fusion of the two cultures" (208). Cf. Leach 1988, 41: "[I]n the study of Roman painting one must accept the proposition that originality does not preclude a blending of Roman and Greek."

${ }^{19}$ The First Style is essentially a Hellenistic style: Bruno 1969; Mielsch 2001, 21-25; Baldassarre, et al.2002,67-70. Tybout 1989,109-86, argues that what we consider the Second Style is only the Romano-Campanian instantiation of a broader Hellenistic koine.

${ }^{20} \mathrm{G}$. Zanker 2004 argues for parallels between the Odyssey Landscapes and Moschus' Europa (50-51) and (pseudo-?) Theocritus 25 (89-91), although he does not claim that the paintings are a copy of a Hellenistic original. Further complicating the question of the origin of the Odyssey Landscapes is that many of the characters in the painting are labeled in Greek; rather than proving the existence of a Greek original, however, the labels are simply another way in which the painting advertises its "Greekness," as Beard and Henderson 2001, 54, aptly note. On the use of Greek labels in Roman wall painting, see Thomas 1995. 
done little to settle the debate: the natural setting of the hunt suggests that Macedonian painters were interested in landscape as more than a mere backdrop to human action, yet the frieze could hardly prevent us from continuing to call the Odyssey Landscapes the first extant example of full-fledged landscape painting in the Western tradition. ${ }^{21}$ As we shall see, the portico frame has been marshaled as evidence in the debate over the true "nationality" of the Odyssey Landscapes, and I shall have more to say on this issue later. Suffice it to say for now that, whatever the antecedents of our fresco may have been, its setting requires us to consider the painting in its Roman context as it was enjoyed by Roman viewers steeped in Greek culture. ${ }^{22}$

\section{THE PORTICO FRAME}

Despite the scholarly controversy surrounding the painting's place of birth, critics readily agree that the painted frame of red pillars was a Roman idea. Yet for the most part, and particularly for those scholars who argue that the Odyssey Landscapes are a copy of a Hellenistic original, the identification of the frame as a Roman contribution to the painting has acted as a sort of back-handed compliment, so that the addition of the pillars becomes one of the Roman innovations that has done a disservice to the Greek "original." 23 Numerous reproductions of the mural do away with the pillars altogether, as though by doing so we might have direct access to a lost masterpiece of Hellenistic art. ${ }^{24}$ Indeed, the very fact that

${ }^{21}$ On the tomb and its frieze (with numerous photographs and line drawings), see Andronicos 1984,97-119. For a similar assessment of the relationship between the landscape of the Vergina frieze and the Odyssey Landscapes, see Small 1999, 568.

${ }^{22}$ As Wallace-Hadrill 1998, 91, puts it in a different context, "To be Roman, go Greek." For other analyses of aristocratic Romans playing Greek in the privacy of their own homes, see Neudecker 1988, 8-30, and Bergmann 2001. The problem of Greek originals and Roman recreations has always plagued Roman art and is becoming a focal point again as an instance of Roman reception of Greek culture; see the three art historical essays in the special volume of Harvard Studies in Classical Philology entitled "Greece in Rome" (Bergmann 1995; Gazda 1995; Kuttner 1995) and the edited volume by Gazda 2002 on emulation.

${ }^{23}$ Von Blanckenhagen's reaction is typical of the critical assessment $(1963,106)$ : "The peculiar and certainly exaggerated fashion of having frames cutting off parts of figures and objects must be explained, all the more because, to my knowledge, this form of 'illusionism' is unique in ancient painting."

${ }^{24}$ Lydakis 2004, 200-201, goes so far as to reconstruct a Hellenistic "original" by putting panels 3 to 5 side by side, without the framing pillars. 
we commonly refer to the painting with the plural "landscapes" (and the individual scenes as "panels" or "pictures") leaves the false impression that the portico frame is not part of the original painting, an impression that is further reinforced by the current arrangement of the fresco in four separate frames (with two panels each) at the Vatican (e.g., fig. 2).

Yet no matter how we understand the origin of the painting, the red pillars deserve consideration in and of themselves, if only because they are a fundamental part of the painting's organization. A hypothetical reconstruction of the frieze as originally arranged makes it clear that the colonnade would have made an immediate impression on the viewer-if not as striking as the landscapes themselves, nonetheless difficult to ignore (fig. 4). Although the pillars at first glance appear to constitute a single row, closer inspection reveals a second row of pillars in the shadows that is partially occluded by the first row, with both rows supporting an architrave and a roof (fig. 6). ${ }^{25}$ The form, then, is that of a portico (Greek stoa, Latin porticus): a covered colonnade that was ubiquitous in Greek and Roman architecture both as a framing device for other spaces (gardens, temple precincts, streets) and as an independent structure. ${ }^{26}$ In the first four panels (plates 1-2), the back pillar can be seen to the right of the front pillar; starting with the second pillar of panel 6 (fig. 1; cf. fig. 4), however, the back pillar appears to the left of the front pillar. The effect, then, is a trick of perspective: the imagined viewing position of the extant frieze is in front of the sixth panel (that is, at the palace of Circe), which is marked as central by the placement of the rear pillars. ${ }^{27} \mathrm{As}$ we

${ }^{25}$ It is not clear whether we are supposed to imagine the second row as freestanding pillars or engaged pilasters along a back wall; in the case of the latter, some of the observations below about figures intentionally "disappearing" behind the pillars would not correspond to the portico as "really" painted, but I would argue that we should not press the realism of the architectural reconstruction too far.

${ }^{26}$ Coulton 1976 offers a history of the Greek stoa, although he is primarily interested in free-standing stoai, not the four-sided peristyles that develop in the Hellenistic period to frame open spaces; on the porticus, see MacDonald 1986, 33-66, and Anderson 1997, $247-50$.

${ }^{27}$ Roman wall painting ensembles of the Second Style usually establish a viewing point (sometimes reflected in the floor decoration) from which the wall is meant to be seen; see Scagliarini Corlàita 1974-76, 9-10, and Clarke 1991,41-45. The differing perspectives of the portico frame (to be viewed from below) and the landscape itself (to be viewed from above) has vexed interpreters of the painting and fuels von Blanckenhagen's hypothesis (1963, 111-12) that the landscape was not originally designed for this setting. As Biering 1995, 160, points out, however, the landscape itself shows little internal consistency of perspective (he compares the size of Odysseus' ships [plate 2] and Circe's palace [fig. 1]), so the expectation of a consistent perspective shared by the landscapes and the portico frame should not be 
shall see further on, this centrality is reinforced by the special status of the sixth panel itself, which distinguishes itself from its adjacent panels both in composition and in narrative technique.

It seems clear then that the painted frame represents a portico, but what kind of portico is this? Would the ancient viewer recognize the form? The question is not an idle one. Vitruvius famously criticized contemporary trends in Roman wall painting for a lack of realism, lamenting the depiction of fantastical architectural features that could not have existed in the real world. ${ }^{28}$ Did a portico such as this, with thin red pillars and golden capitals, exist in the ancient world? It is not immediately apparent what material these red pillars are supposed to represent: are they painted wood, painted stucco, or some sort of fantastically colored marble, like the surreal colors boasted by the panels of the late First Style of Pompeian wall painting? ${ }^{29}$ Although it is true that porticoes typically employed cylindrical columns and not pillars for support, there are exceptions. The so-called Hall of the Doric Pillars at Hadrian's villa has monumental marble pillars for supports. ${ }^{30}$ On a somewhat humbler scale, the Praedia of Julia Felix at Pompeii boasts a two-sided colonnade with slender pillars that are very similar in impression and scale to the narrow pillars of the Odyssey Landscapes (fig. 7). ${ }^{31}$ Similarly, although the Greek stoa almost always featured columns, marble pillars were used on occasion; considering the possibility that the Odyssey Landscapes portico was displayed at some height, the use of rectangular pillars on the upper level of two-story stoas at Delos is particularly noteworthy. ${ }^{32}$ In addition to these examples, we can only assume that wooden pillars

assumed. Moreover, there is the possibility that the intended illusion was not that we are looking out at a "real" landscape but that we are looking at a representation of a portico decorated with a landscape painting: a representation of a representation. If this is the case, we would not expect a consistency of perspective between frame and landscape.

${ }^{28}$ Vitr. De arch. 7.5.3-8; on the passage, and its relationship to Third Style ensembles, see Ehrhardt 1987, 152-62; Clarke 1991, 49-53.

${ }^{29}$ The gilded capitals might suggest marble, but the garish red seems a bit too bright for rosso antico, which is how Biering 1995, 21, identifies the material. If this is meant to simulate marble, perhaps we are meant to imagine that the marble is painted?

${ }^{30}$ MacDonald and Pinto 1995, 80, interpret the space as a basilica, renaming it the "Ceremonial Precinct," "a spacious building for state business and occasions."

${ }^{31}$ On the portico, see Parslow 1989, 267-69, esp. n. 153 for analogs in wall painting (including the Odyssey Landscapes) and in Italian archaeological remains.

${ }^{32}$ On the use of rectangular pillars instead of columns in Greek architecture, including their use as "the characteristic feature of the Delian upper order," see Coulton 1976, 129-30. 
were a common support for simpler porticoes, but these would obviously not survive to the present day.

A more useful point of comparison for our portico is offered by Roman wall painting itself, and this is the usual point of reference in scholarly discussions of the portico frame. One of the hallmarks of the Second Style of Roman wall painting is the opening of a wall, in a trompe l'oeil effect, onto a seemingly endless receding architectural vista. ${ }^{33}$ Supporting columns are an essential feature of this decoration, giving the sense of monumental civic or religious space; the Second Style paintings from the Villa at Oplontis are a well-known example. Occasionally such decoration includes porticoes supported by slender pillars, very much like the ones that front the Odyssey Landscapes, such as the fresco from room 23 of the Villa at Oplontis or the west wall of room 5 (the Room of the Masks) in the House of Augustus on the Palatine (fig. 8). ${ }^{34}$ Similarly, we may look to contemporary wall painting for examples of painted porticoes being used as a fictive frame for the rest of the painted wall. Room 6 (the Room of the Garlands) in the House of Augustus has a series of thin red and yellow pillars on three of its sides (fig. 9); the upper part of the wall is thereby divided into "panels" quite similar to the Odyssey Landscapes, though the framed view gives onto another colonnaded courtyard instead of a mythological landscape. ${ }^{35}$ In room 2 of the House of the Griffins on the Palatine, columns with bosses appear to project from the wall; such decor has been interpreted to correspond to the actual columns of the peristyle onto which the room opens (fig. 10). ${ }^{36}$ Scholars have seen numerous points of reference for the profusion of colonnades and porticoes in the Second Style, including public sacred architecture, theatrical design, and palatial grandeur. ${ }^{37}$ Eleanor Winsor

${ }^{33}$ On the historical development of the Second Style, see esp. Beyen 1960, 13-33.

${ }^{34} \mathrm{Cf}$. also the second-style decoration in room 20 of the House of the Cryptoporticus at Pompeii (1.6.2-4); see Pugliese Carratelli 1990-2003, vol. 1, p. 231 (figs. 65-66). Most scholars have seen in these porticoes the influence of scaenae frons architectural design (see, e.g., Leach 2004, 93-100), though it is worth pointing out that the stage fronts themselves are trying to evoke the grandeur of palatial porticoes.

${ }^{35}$ Room 12 (The Ramp Entrance) in the House of Augustus also has an upper zone framed by pillars, though at a much greater height; see Carettoni 1983 table 98 (and color table 2 for the north wall of the Room of the Garlands). Cf. also room y of the House of the Silver Wedding at Pompeii (5.2.1); see Pugliese Carratelli 1990-2003, vol. 3, pp. 747-49 (figs. 153-57).

${ }^{36}$ Clarke 1991, 41-45. Cf. also room 39 of the House of the Labyrinth (Strocka 1991, figs. 239-43).

${ }^{37}$ For a useful discussion of the various points of reference, real and imaginary, of the Second Style, see Barbet 1985, 44-52; see also Ehrhardt 1991. 
Leach has argued that what she terms the "porticus" style reflects similarly luxurious decoration in late republican domestic space, where colonnades and porticoes were an essential feature; as we shall see, this, too, is where I believe we should look to understand the full reference of the frame of the Odyssey Landscapes. ${ }^{38}$

A final point of comparison for the function of the Odyssey Landscapes frame is the common ancient practice of displaying art in stoas and porticoes. Colonnades were often used as art galleries; most famously, the stoa poikile in Athens earned its name from the paintings displayed there. These depicted various highlights in Athenian military history, including the battle of Marathon and even the Trojan War. ${ }^{39}$ The fact that the stoa was an ambulatory space no doubt contributed to its use as a venue for the display of art. The tradition continues in the public porticoes that appear around Rome in the late republic, most notably in the Portico of Pompey ${ }^{40}$ We know from Pliny the Elder, for example, that panel paintings of the Trojan War decorated the late republican Porticus Philippi in Rome (HN 35.144). ${ }^{41}$ The appeal of placing artworks in a space explicitly designed for leisurely strolls was in no small part due to the fact that the movement of the viewer contributed to the creation of a narrative flow. In a few cases, most notably the Telephos frieze at Pergamon, in which a narrative sculptural frieze is positioned in a three-sided portico, the connection between the movement of the viewer and the movement of the story is explicit..$^{42}$ Furthermore, the proximity of the columns and the frieze demands that the viewer step outside the portico to see any significant stretch of narrative; the Telephos frieze thereby becomes a real-life analog for the Odyssey Landscapes by its use of architectural supports to divide and frame a continuous narrative. In fact, von Blanckenhagen argues that the hypothetical original may have decorated the wall of a

${ }^{38}$ On the "porticus style," see (most recently) Leach 2004, 85-92. On the use of columns as framing elements in Roman domestic architecture, see Wallace-Hadrill 1994, 35-36; on framed views more generally as a characteristically Roman phenomenon, see Drerup 1959 (though I would qualify somewhat his claim on p. 149 that such views are not intended to be enjoyed while walking).

${ }^{39}$ See Pausanias 1.15.1-4.

${ }^{40}$ On the portico of Pompey, see Gleason 1990 and Kuttner 1999.

${ }^{41}$ The portico, with its double colonnade and Homeric paintings, is a possible influence on the Odyssey Landscapes; on the portico, see Richardson 1977, 359-61.

${ }^{42}$ The connection between the Telephos frieze and the Odyssey Landscapes is made by von Blanckenhagen 1957, 80. On the narrative art of the Telephos frieze, see Stewart 1996. 
portico, so that the Roman addition of the painted frame may be trying to evoke the original viewing experience. ${ }^{43}$

As it happens, a passage in Vitruvius offers corroborating evidence that landscape painting was especially common as a display in porticoes. He gives an aetiology of sorts for the Second Style, and in the process reveals that the Odyssey Landscapes as we know them may in fact be the only surviving example of a subgenre (De arch.7.5.2.):

Postea ingressi sunt ut etiam aedificiorum figuras, columnarum et fastigiorum eminentes proiecturas imitarentur, patentibus autem locis uti exedris propter amplitudines parietum scaenarum frontes tragico more aut comico seu satyrico designarent, ambulationes vero propter spatia longitudinis varietatibus topiorum ornarent a certis locorum proprietatibus imagines exprimentes - pinguntur enim portus, promunturia, litora, flumina, fontes, euripi, fana, luci, montes, pecora, pastores-nonnulli locis item signorum megalographiam habentes deorum simulacra seu fabularum dispositas explicationes, non minus Troianas pugnas seu Ulixis errationes per topia, ceteraque, quae sunt eorum similibus rationibus ab rerum natura procreata.

Later, they also began to imitate the forms of buildings, and the projecting grandeur of columns and pediments. Moreover, in open spaces such as exedrae, because of the size of the walls, they began to draw stage settings in the tragic, or comic, or satyric mode. At the same time, they began to decorate ambulatory spaces, on account of their great length, with varieties of landscape, modeling their pictures on the true characteristics of places (for there are paintings of harbors, headlands, shores, rivers, springs, straits, shrines, groves, mountains, livestock, shepherds), with some in places even including paintings of statues, likenesses of the gods or the organized unfolding of stories, and even the battles of Troy, or the wanderings of Odysseus through landscape, and other things which, in ways similar to these, were begotten by nature. ${ }^{44}$

${ }^{43}$ von Blanckenhagen 1957, 80; see also Vlad Borrelli 1956, 299. Cf. von Blanckenhagen 1963, 126: "[W]e may call the original Odyssey frieze a painted counterpart to [the Telephos frieze.]" While such a specific source for the portico frame seems to be a bit too neat, the general use of the portico as a frame in the Second Style has been traced to the Hellenistic practice of using real porticoes as frames (see Robertson 1955, 59). As Osborne 1987 has shown, however, the manipulation of views through a colonnade and the forced participation of the viewer's movement in the creation of the meaning of an artwork are at least as old as the Parthenon frieze.

${ }^{44}$ On the passage, Tybout $1989,55-107$, is essential; he however prefers the reading nonnullis locis (attested in a few manuscripts), making the final part of the passage refer to "some spaces" (in general), and not just ambulationes (see pp. 76-77). As is clear from my translation (and from what follows), I prefer the majority manuscript reading (and lectio difficilior) nonnulli locis; in any case, I see the connection between Homeric myth 
As many commentators have noted, the natural features that Vitruvius identifies as constitutive of the genre of landscape painting-harbors, headlands, shores, rivers, and so on-can all be found in the Odyssey Landscapes; even without the explicit reference to "the wanderings of Odysseus through landscape," we would surely be reminded of our painting. ${ }^{45}$ Vitruvius' tone in this passage is the positive version of the moralizing aesthetic reaction to the Third Style that we witnessed above: he approves of the Second Style for its commitment to depict things drawn from the real world, whether natural or manmade. (Surprisingly, the depiction of mythical cycles fits the definition of "realistic," for myth also belongs to the world of the "manmade.") Similarly, he posits a "natural" relationship between the subject of wall painting and its architectural setting (and, by extension, its viewing context): spaces that are enclosed and offer the viewer a chance for stationary contemplation are more suited to architectural displays, while longer spaces invite the strolling viewer to appreciate the subtle variations of landscape along a longer wall. ${ }^{46}$ The painted portico draws attention to the participation of its viewers in the unraveling of the story that is depicted before them; it is a visible reminder, a metaphor for the viewers' act of walking, which is integral to both the act of viewing and the act of interpreting the frieze. In the section that follows, I will look at some of the ways in which the painted portico of the Odyssey Landscapes achieves a similar narrative effect, as the viewer is led through this imaginary ambulatio.

\section{THE NARRATIVE WALK}

Ralf Biering, in his recent study of the Odyssey Landscapes, has shown through ultraviolet photography that the framing pillars were sketched before the rest of the painting, proving that they formed an integral part

and ambulatory space that Vitruvius seems to be making here as circumstantial evidence and not essential to my argument.

${ }^{45} \mathrm{Cf}$. Pliny's famous description (HN35.116-17) of the landscapes of the Augustan-era painter Studius, though Ling $(1977,3)$ argues that Pliny's description does not correspond well to the Odyssey Landscapes.

${ }^{46} \mathrm{As}$ it happens, the correspondence is not as common as Vitruvius would suggest, or at least not in our extant remains; for the evidence, see Tybout 1989, 97-107, who concludes that Vitruvius has the general picture right (i.e., that the size of rooms was an important influence on Second-Style wall ensembles) even if the specific details do not withstand scrutiny. Scagliarini Corlàita 1997 draws a similar conclusion about Vitruvius' description of ambulatory spaces. 
of its genesis. ${ }^{47}$ Yet the underdrawing of the architectural frame does not by itself disprove the theory that the painting is a copy of a Hellenistic original; its most vocal proponent, von Blanckenhagen, in fact insisted that this must have been the case, claiming that "the place of the pillars must have been fixed before the painting of the frieze started." ${ }^{8}$ Von Blanckenhagen interprets as a sign of careful planning the fact that the pillars do not occlude any important scenes; yet, paradoxically, he interprets the fact that a few less significant figures are cut off by the portico as a sign that the painting was originally conceived as a continuous landscape without an architectural frame and that these small characters would not have been covered in the original. One could, however, draw precisely the opposite conclusion. Having some events partially concealed by the pillars only heightens the illusion that there is an actual portico through which the viewer sees the landscape. Given how many figures there are in the third panel (some sixteen, not including animals: plate 1; cf. fig. 11), it would look somewhat strange if all the action managed to keep itself within the frame of the two pillars; to maintain the illusion, the painter must give the impression that the action takes place without knowledge of the painted frame ${ }^{49}$ The disappearance of none but insignificant figures behind the pillars thus argues all the more compellingly that this painting was conceived for its original location, pillars included.

In all the sections but one, the portico clearly serves to frame one particular episode of the Homeric narrative, so that each panel is in some sense describing one action. ${ }^{50}$ Yet at the same time there are elements in each scene that serve to bridge the gap from one side of the pillar to the next. In panel 2, for example (plate 1), in which Odysseus' men are greeted by the Laestrygonian princess, the overall mood is one of deceptive tranquility. Such a mood is reinforced by the peaceful characters who frame the main action of that scene, such as the reclining figure just to the left, watching the scene with no apparent malice. ${ }^{51}$ Another figure lies on the rock above the Laestrygonian princess, suggesting that the place from which she has just come is a peaceful one. Most important

${ }^{47}$ Biering 1995, 23-25.

${ }^{48}$ von Blanckenhagen 1963, 111.

${ }^{49} \mathrm{Cf}$. Biering 1995, 164, who points out that the pillars are not merely frames for the action but rather create an additional level of illusion. Ling 1991, 111, makes a similar point, though he still treats the frieze as a copy, albeit "freely adapted."

${ }^{50}$ The exception, panel 6 (fig. 13), is famous for its simultaneous depiction of two distinct moments in the Circe story; see below.

${ }^{51}$ She is usually identified as a personification of the spring; according to Biering 1995,125 , only the last two letters of her label [KPH]NH are still legible. 
for our purposes is the pastoral scene to the right of Odysseus' men, which extends into the first third of the next panel. The cowherds, the shepherd reclining on a rock, and the goats drinking from the spring all lull the viewer into the same dangerous complacency that will be the doom of Odysseus' men, whose backs are literally turned to the looming violence in panel $3 .^{52}$ The peaceful mood is in fact transported into the next scene by the cowherd who disappears behind the red pillar (thereby echoing the movement of the viewer) and by the spring that runs from one section to the next. The portico therefore plays an important part in the narrative strategy; as the pastoral scene progresses before, behind, and after the pillar, the viewer is fooled into thinking that the pillar is in fact not a frame at all, since it is not transitional here and does not seem to separate scene from scene. This reinforces the false sense of security evoked by the scene itself and renders the violence of the Laestrygonian attack all the more sudden and frightening. ${ }^{53}$

The third panel keeps the narrative moving forward by maintaining the overall left-to-right movement of the first scene: the violence is introduced by the first Laestrygonian bending a tree to the right and thereby pointing us to the focal point of the panel (plate 1). Yet there is also a Laestrygonian pulling a Greek from the swamp in the lower right corner; his movement, in the opposite direction, adds to the energy and confusion. The counterpart to this vignette is the one immediately to its right, a little further in the background, where the violence enacted on the dying Greek is similarly reinforced by the truncated representation of his body, although here the body is covered not by marshy water but by the familiar red support of the portico. The effect, however, is no less disturbing; despite the fact that we cannot see him, we have no doubt about his violent end. The portico therefore has a similar narratological function as before. As the Laestrygonian pushes the helpless Greek both underwater and "offstage," we realize that the violence will spill over

${ }^{52}$ As Lowenstam 1995, 197-98, points out, the presence of the pastoral scene is most likely a reference to Odysseus' description of the Laestrygonian land as a place where the night is so short that "in that place a man who did not sleep could have earned two paychecks, one for driving cattle, and the other for herding white sheep; for close together are the paths of night and day" ( $\operatorname{Od} 10.84-86)$. Moreover, as the reader for AJP points out, Odysseus sends his scouts after surveying the land from on high and noticing no traces of men or cattle (Od.10.97-102); here we see the first sign of what was not visible in that initial survey.

${ }^{53}$ The antithesis of tranquility and violence also mirrors the Homeric episode, which "begins as if it were going to be another Phaiakis, but transforms itself unexpectedly and horrifically into another Cyclopeia" (Cook 1995, 71). 
into the next frame. As in the first instance, the pillar not only serves to define the third section, allowing us to give the picture one coherent reading, but it also propels the story forward, making it apparent that the violence cannot be contained by the visual frame.

The organization of the fourth panel is quite different from the previous two; there is a certain symmetry enforced by the embracing arms of the bay, but the effect is to emphasize the dwindling prospects for Odysseus' men (plate 2; cf. fig. 12). Whereas the first two panels depicted a clear movement from left to right, the fourth panel draws our eyes to the middle; encouraged by the symmetry, we focus our attention on the bay no less intently than the Laestrygonians do, as they destroy the Greeks and their ships. Unlike the previous two transitions, there is no occluded figure to encourage movement to the next scene, and the viewer is just as trapped between those two pillars as the Greeks are in that narrow bay. Yet the violence does spill over somewhat into the next frame: on the bottom left corner of panel 5 there is a Laestrygonian about to crush a tiny Greek victim with a rock (plate 2). While the previous sections had figures that propelled the narrative forward, here we have a little scene that looks back to the previous one. It is the analog of the death found at the right edge of panel 3, in which the Greek is being pushed underwater. The symmetrical arrangement of the two murders, flanking the pillars in panel 4, intensifies the narrative pause of the fourth scene.

But one ship does escape, and the fifth panel moves forward while we follow it as it appears from behind a huge rock (plate 2). It is in fact the first appearance of Odysseus in the extant narrative, a dramatic entrance confirmed by the nametag inscribed above the ship; the viewer will now remember from the Homeric story that Odysseus had the foresight that his companions lacked: he leaves his ship outside the narrow harbor $(\mathrm{Od}$. 10.95-96). The section is in some sense similar to the previous one, with land on each side and water in the middle. But this is a strait, whereas the other was a bay. The effect of the scene is one of transition, in contrast to the confining danger of panel 4 . The painter emphasizes the transition by contrasting the violent scene on the left side of the panel with the peaceful one on the right where the personifications of the shoreline (labeled aktai) recline. The figure on the right of panel 5 in particular recalls the krene personification from panel 2, and the attentive viewer should recall that the tranquility which this figure introduced was in fact an illusion. And while the violent scene on the lower left looks back to the previous panel, the figures on the right look forward to the next scene, pointing the narrative past the pillar and into the house of Circe.

As noted earlier, panel 6 is marked as the central panel by the 
architectural perspective of the columns (fig. 13). Aside from this, there are other features that distinguish it from the rest of the extant frieze. Here for the first time the action takes place not in landscape but in an architectural setting, namely, the palace of Circe. Moreover the design of the palace evokes the more familiar architectural ensembles of the Second Style, particularly the semicircular exedra at the right and its two columns that frame an interior aedicula. ${ }^{54}$ Yet it is clear that the painter has partially collapsed the boundaries between outside and inside; not only are we situated in a courtyard with a tree, but the courtyard itself is also not clearly demarcated by architecture, and, despite Odysseus' entry through the front door, the courtyard appears to be open to the surrounding landscape. Furthermore the house itself, with its yellow-brown stucco, plainly recalls the cliffs depicted earlier in the frieze and blends quite naturally into the existing landscape.

The Circe panel is also distinguished from the rest of the frieze by its narrative experimentation: the painter has juxtaposed two different moments in time in the same frame, almost side by side. On the left, Circe greets Odysseus at the door, and on the right, Odysseus draws his sword on the sorceress. The panel is therefore a particularly dramatic example of continuous narrative in which two or more different episodes involving the same characters appear against the same backdrop. ${ }^{55}$ Strictly speaking, the entire Odyssey frieze is a continuous narrative, since Odysseus appears numerous times along the length of the painting. In this sense, the Odyssey Landscapes employ a narrative technique familiar from Hellenistic art, such as the Telephos frieze at Pergamon..$^{56}$ The Odysseus and Circe panel, however, is an instance of what von Blanckenhagen (1957,

${ }^{54} \mathrm{As}$ the anonymous reader for $A J P$ points out, the perspective of this panel makes the aedicula the focal feature of the background, just as the panel itself is the focal point of the framing portico. Aediculae or tholoi framed by columns are a common feature of larger Second-Style ensembles, such as the east and west walls of triclinium 14 at the Oplontis villa and the east and west walls of room 43 (the so-called Corinthian oecus) of the House of the Labyrinth at Pompeii (see Strocka 1991, figs. 287-92); on framed views of tholoi, see Tybout 1989, 315-23.

${ }^{55}$ Cf. Stansbury-O'Donnell 1999, 146: "Continuous narration is one in which the agents reappear against a common background in an integrated pictorial field, with time shifting from one scene to the next and space either changing or remaining the same." For a useful introduction to the scholarship on ancient visual narrative, see StansburyO'Donnell 1999, 1-8.

${ }^{56}$ Carl Robert, the first scholar to develop a history of ancient visual narrative, was also the first to identify continuous narrative as a characteristic of Hellenistic art (earlier examples notwithstanding); see Robert 1881, 46-50. 
81) called "strict" continuous narrative, in which the same character(s) are depicted in the same visual field at two distinct moments of the story. ${ }^{57}$

It is not a coincidence, I would argue, that this narrative play comes at the exact center of the extant frieze. The sixth panel confirms the connection between the narrative movement of the painting and the walk of the viewer, for both acts of movement are halted in the same frame: the viewer is encouraged to linger on this scene by the perspective imposed by the portico, which marks the place where the ideal viewer might stand and contemplate the entire wall. Moreover, the narrative paradox of the Circe panel occurs at precisely the moment where the portico frame offers the viewer a similarly ambiguous narrative message. Just as the narrative strategy of the painting expects the viewer both to follow a narrative progression over time in the first few panels and to take in two different moments in time in the sixth panel, the portico frame conveys to the viewer two contradictory suggestions: to walk the length of the wall through this fictive ambulatory space and at the same time to view the entire wall while standing in front of the central panel. In fact, we might say that the viewer, like Odysseus in this scene, is asked to be in two places at once..$^{58}$

For the moment I will leave aside a consideration of the panels that follow the sixth panel, in part because there is less to work with (the seventh panel [fig. 1] is essentially destroyed, while the Sirens panel [fig. $3]$ is fragmentary, leaving only the one and a half panels depicting the underworld intact) and in part because these panels will play a larger role in a later section of this article. For now, having established that the portico frame posits a connection between the walk of the viewer and the narrative movement of the painting, I want to consider how the frame also establishes a connection between the walk of the viewer and the subject of

${ }^{57}$ Von Blanckenhagen argues that this type of continuous narrative was a Roman development, and there are indeed many examples in Pompeian wall painting (see, for example, Leach 1981 and 1986); since he believes that the Odyssey Landscapes are a copy of a Hellenistic original, this forces him to argue that the addition of a second set of Odysseus, Circe, and servant is in fact (along with the portico frame) the only Roman contribution to the painting. For the suggestion that continuous narrative is a legacy of Roman triumphal painting, see Holliday 2002, 89. The best study of Roman visual narrative techniques remains Brilliant 1984.

${ }^{58}$ For a similarly playful use of continuous narrative, see Leach's reading (1981, 315-16, 319-20) of the Diana and Actaeon panel from the Casa del Frutetto in Pompeii; in that painting, the painter depicts Actaeon at three different stages of his encounter with Diana, and the manipulation of the viewer's shifting gaze evokes both the metamorphosis of the hunter and the act of viewing central to the myth itself. 
the painting, namely, the journey of Odysseus himself. To do so, we must examine a little more closely the function of ambulatory spaces-and the very act of walking itself-in contemporary Roman society.

\section{THE STROLLING VIEWER}

Earlier in this article I alluded to the fact that the Odyssey Landscapes' use of a fictive portico as a frame would not have seemed unusual to ancient viewers, since real porticoes were frequently used as settings for art displays in the ancient city. The portico, however, was a ubiquitous presence not only in the Greek and Roman urban landscape but in Roman domestic architecture as well. The Pompeian townhouse of the late second century B.C.E. (the so-called "atrium house") expands to accommodate a peristyle at the back, an open court or garden surrounded by covered colonnades (hence Vitruvius' use of the term peristylium). ${ }^{59}$ The use of a Greek word to describe this new space is telling, and the shift from atrium house to peristyle house is usually understood as a reflex of the increased Hellenization of Roman culture. ${ }^{60}$ In particular, the peristyle offered a space for privileged access at the rear of the domus, as opposed to the more public atrium at the front of the house ${ }^{61}$ Larger peristyles (such as those in the House of the Faun at Pompeii) would allow the homeowner to offer his privileged guests a space for ambling conversation, a space that advertised not only the wealth but also the culture of the dominus. ${ }^{62}$ Smaller peristyles may or may not have provided enough space for a relaxed stroll but in either case conveyed the homeowner's commitment to a Hellenized leisure.

The portico was also an essential element of villa design, and it is to the villa that we must look for the fullest expression of the message that the portico frame of the Odyssey Landscapes sought to convey to the viewer. As with the peristyle in the urban domus, the emergence of the country villa as a leisure space and an intellectual retreat can be dated

\footnotetext{
${ }^{59}$ Despite the almost universal adoption of the term "peristyle" in modern literature, the use of peristyl(i)um to describe this part of the house is extremely rare outside of Vitruvius' work; see Maiuri 1946, 306-16, and Leach 1997, 59.

${ }^{60}$ On the peristyle in the Campanian domus, see Maiuri 1946, 316-22; Wallace-Hadrill 1994, 20-23; Dickmann 1997; and Leach 2004, 34-40. For a critique of the traditional evolutionary model, see Wallace-Hadrill 1997.

${ }^{61}$ Wallace-Hadrill 1994, 38-60, is the most useful treatment of the different levels of access in the domus; see also Grahame 1997 and Dickmann 1999, esp. 41-48.

${ }^{62}$ On the peristyles of the House of the Faun, see Dickmann 1997.
} 
to the second century B.C.E., and it is often understood as part of the same phenomenon of Hellenization. ${ }^{63}$ Varro's well-known diatribe against the practice of naming every nook and cranny of the Roman villa after a Greek prototype (Rust. 2 pr. 2) is in part a parody, but it testifies to the greater truth that the Roman villa, removed from the disapproving gaze of the urban populace, became the place where the negotiation of Greek and Roman cultural identity played out. One such "negotiation" was the use of portico spaces to evoke the atmosphere of the Athenian gymnasium. ${ }^{64}$ Cicero's philosophical dialogues are especially instructive here; in the De oratore, for instance, one of the characters explicitly compares the portico of Crassus' Tusculan villa in which they are walking to similarly appointed Greek gymnasia and palaestrae..$^{65}$ We may be tempted to dismiss such comparisons as part of the literary staging, since the dialogue self-consciously sets itself up in emulation and rivalry with Plato's Phaedrus; the characters even sit under a plane tree at one point. ${ }^{66}$ Yet Cicero's private correspondence also attests to the Roman fashion for equipping villas with Hellenized spaces. He shows great concern in a number of letters to Atticus that his new Tusculan peristyle be decorated in a fashion appropriate to a palaestra and gymnasium, notoriously going so far as to refer to it quite regularly as his "Academy" (his "Lyceum" would be added later). In doing so, he was following the lead of his

${ }^{63}$ For the Romans, the luxury villa resulted from the importation of urban comforts to the country (cf. Columella's identification of the domestic quarters of the farmhouse as the villa urbana: Rust.1.6.2), but P. Zanker 1998, 135-203, has shown that the influence also flowed in the opposite direction and that domus design owed a great deal to villa fashions. On the villa as a locus of Hellenization, see Mielsch 1987, 94-116; Neudecker 1988, esp. 5-30; P. Zanker 1988, 25-28, and 1998, 136-42; Beltrán Fortes 1995; and Bergmann 2001.

${ }^{64}$ On the history and social function of the Greek gymnasium, see Delorme 1960 and Fisher 1998.

${ }^{65}$ De or. 2.20: “. . . in quo porticus haec ipsa, ubi nunc ambulamus, et palaestra et tot locis sessiones gymnasiorum et Graecorum disputationum memoriam quodam modo commovent" ("... where this portico in which we now stroll, and this palaestra, and so many places to sit evoke somehow the memory of the gymnasia and the philosophical disputes of the Greeks"). Catulus' comment is followed by a counterargument by Crassus (2.21), who insists that the primary association of Greek palaestrae is with exercise of the body and not the mind; the dissonance nicely encapsulates the eclectic character of Roman domestic decor even on the level of symbolic reference. In fact, in most of Cicero's dialogues the characters do not stroll but rather sit, in emulation of an even stronger tendency in Plato's dialogues; nonetheless, as I have shown elsewhere (O'Sullivan 2006), Cicero's dialogues bear eloquent witness to the symbolic power of walking in particular as a philosophical pose.

${ }^{66}$ On the literary staging of the dialogue and the correspondences with Plato's Phaedrus, see Görler 1988. On the evidence for the use of plane trees in Roman landscaping, see Jashemski 1979, 51-53, 331. 
contemporaries, who strove to recreate in the seclusion of their country estates various natural and manmade landmarks from the Greek east. ${ }^{67}$

The aim of evoking the world of the gymnasium in the private home was clear: these were spaces intended to advertise the intellectual refinement of the homeowner, spaces for conversation and reflection with friends. The Greek civic spaces that offered a setting for the intellectual gymnastics of philosophers had been transplanted to private retreats in the Roman countryside, where not only the architecture and decor (statues, paintings) but even the poses of the gentlemen (sitting on benches, strolling in porticoes) recreated Hellenized repose. Particularly essential to this recreation were ambulatory spaces: not only porticoes but also garden paths, cryptoporticoes, and xysti. ${ }^{68}$ For the leisurely walk itself, the ambulatio, was a mainstay of a Hellenized aristocratic leisure; in particular, the act of walking for leisure in the Roman villa was associated with philosophical discussion and private contemplation, and the leisurely walk of the aristocrat was intuitively understood to be an appropriate occasion for the acquisition of knowledge. As Bettina Bergmann has shown, a walk through a country villa, decked out with the art and architecture of other times and places, was akin to traveling through an imaginary Greece, so that the benefits of traveling abroad for both edification and pleasure were recreated, on a smaller scale, in one's own backyard. ${ }^{69}$

I suggest that the portico frame of the Odyssey Landscapes was intended to put the viewer in just such a mindset, acting as a filter for the viewing experience; the portico, a space that is both Roman and Hellenized at the same time, mediates for the viewer the transition between the landscapes of the painting-Greek, outdoors, rural—and

${ }^{67}$ Cicero mentions his Academy (either by name or by indirect reference) in a number of early letters to Atticus (see Att.1.4, 1.6, 1.8, 1.9, 1.10,1.11); on his "Lyceum," see Div.1.8. For the villa decoration of Cicero and his contemporaries, see Neudecker 1988, 8-30. On the phenomenon of naming parts of the villa for other places, see Görler 1990, 169-74.

${ }^{68}$ According to Vitruvius (Arch. 5.11.4 and 6.7.5), the Roman xystus (or xystum) was an open-air walkway, unlike the Greek $\xi v \sigma \tau$ ó, which was covered; the discrepancy suggests that the effect of these borrowings was felt to be more important than their accuracy.

${ }^{69}$ Bergmann 2001, 158, in fact draws a parallel (as I do) between the travels of Odysseus as represented in the Odyssey Landscapes and the ambulatio of the Roman aristocrat (though without explicit reference to the portico frame): "The Odyssey Frieze is one of many integrative landscapes in which a story could evolve in stages or a figure enact his life in a kind of cinematic flow. That movement through a constructed realm was physically experienced by visitors to a well-outfitted park or villa garden, who could 'travel' the world, from present to past and back again, by passing through provocative zones filled with the appropriate regional vegetation and figures from a myth or historical event." 
the landscape of his domestic environment-Roman, indoors, urban. The portico therefore becomes not only a narrative frame but an interpretive frame as well; it is the advertisement of the intellectual refinement and the intimate knowledge of Greek literature and philosophy now essential for any member of the Roman elite. To the Roman viewer, it is just as assertive as the Greek words inscribed on the frieze or the Greek subject matter that fills the landscape; architecture, too, has its own syntax, and the associative chain enacted by those red pillars would not be lost on a Roman viewer of the late republic.

More than any other Second Style painting, I would argue, the portico frame and the associations it brings to the act of viewing are especially appropriate for the subject of the Odyssey Landscapes. As we have seen, the portico would evoke in the viewer an array of associations, including the cultural metaphor that correlated the movement of the body with travel and the acquisition of knowledge and, similarly, physical movement with intellectual inquiry: precisely, in other words, what the hero depicted on the other side of the fictive portico was famous for. The portico frame mediates between the walk of the viewer and the travels of Odysseus himself. In the final section of this article we will see what philosophical lessons the viewer, put into the right frame of mind by the intellectual associations of the portico, might acquire by walking with Odysseus.

\section{PHILOSOPHICAL WANDERINGS}

By the first century B.C.E., it was a commonplace that Homer could be considered the father of philosophy, with various schools competing for the right to claim him..$^{70}$ The mining of Homeric poetry for philosophical lessons is especially associated with the Stoics, but they did not, as Philodemus makes clear, claim exclusive rights to the activity: "so we hear that Homer is said to be the inventor of philosophy by not merely the critics but the philosophers themselves, and not those from one school only but from all." 71 Treating Homer as the "inventor" of philosophy is in part a

${ }^{70}$ The bibliography on this topic, both in ancient and modern sources, is enormous. The best single resource is Buffière 1956, a survey of philosophical readings of the Iliad and the Odyssey, with an emphasis on allegorical interpretation; also useful are the essays in Lamberton and Keaney 1992. On philosophical readings of the Odyssey and Odysseus in particular, see Buffière 1956, 365-91, and passim; Stanford 1963; Kaiser 1964; and Rutherford 1986.

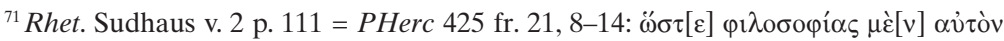

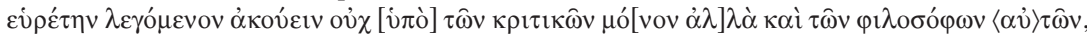


reflex of a more general tendency to treat the Iliad and the Odyssey as the foundational texts of Greek culture and to refer to Homer as an authority that all Greeks could share. ${ }^{72}$ Yet the practice of Homeric exegesis by ancient philosophers was also inspired by specific philosophical questions that the texts raised; for example, allegorical readings of Homeric characters and episodes were popular in part because they excused Homer for his "immoral" representations of the gods, who could now be read as allegories of the physical world. ${ }^{73}$

Even where full-scale allegory was not the immediate goal, the poetry of Homer offered numerous "starting points" ( $\dot{\alpha} \varphi \rho \rho \mu \alpha i)$ for philosophical inquiry, particularly as a source of ethical recommendations for human behavior. ${ }^{74}$ It is the latter for which Odysseus was a useful model, and not only because he is the most developed character in the Homeric corpus. The journey of a hero who sees the towns and comes to know the minds of many people was, and is, an irresistible metaphor for the human condition and our journey through life, and, as Richard Rutherford in particular has shown, we should not allow the later history of sometimes fanciful moralizing readings of the Odyssey to obscure the fact that the poem itself encourages such readings. ${ }^{75}$ Still (or predictably), different schools were attracted to different aspects of Odysseus' journey. Stoic readers chose to emphasize Odysseus' long sufferings and his steadfast pursuit of his homecoming, even in the face of powerful temptations. According to Seneca, "our own Stoics have regarded Odysseus and Heracles as wise men, since they were unconquered by labors and despised pleasure and conquered all lands." ${ }^{.76}$ Cynics also promoted

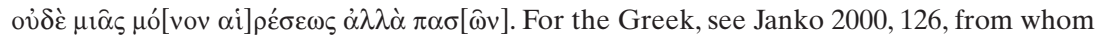
I have also taken the translation.

${ }^{72}$ See Buffière 1956, 10-13; Nagy 1979, 6-11.

${ }^{73}$ According to the scholiasts, the presocratic philosopher Theagenes of Rhegium was the first to employ allegorical interpretation in defense of Homer; see Theagenes (DielsKranz 8) A2. On Theagenes and the origins of allegoresis, see Ford 1999. On allegorical readings of Homer, see Buffière 1956, 45-65; Hardie 1986, 22-29.

${ }^{74}$ See Asmis 1991, 20-21, for Philodemus' use of the term with reference to Homer in On the Good King according to Homer (PHerc 1507) col. 43.16-20.

${ }^{75}$ Rutherford 1986. Cf. Hartog 2001, 15-39, who reads the Odyssey as "poetic anthropology" (25) and explores the ways in which both the poem and the figure of Odysseus participate in the construction of Greek identity. On the allure of Odysseus' wanderings as a model for intellectual inquiry in the fifth century B.C.E., see Montiglio 2005, 123-29.

${ }^{76}$ Sen. Dial. 2.2.1: "Hos [sc. Ulixem et Herculem] enim Stoici nostri sapientes pronuntiaverunt, invictos laboribus et contemptores voluptatis et victores omnium terrarum." Cf. Cic. Leg. 2.3, who calls Odysseus "the wisest / most philosophical man" (ille sapientissimus vir). On the Stoic Odysseus, see Buffière 1956, 374-77, and Stanford 1963, 121-27. 
Heracles and Odysseus as models of self-sufficiency and prototypes for proper behavior in difficult circumstances. ${ }^{77}$ Perhaps most surprisingly, there were also prominent Epicurean interpretations of Odysseus' behavior, despite the school's legendary reputation for hostility to poetry. ${ }^{78}$ Odysseus' words in praise of the pleasures of the banquet in the palace of Alcinous (the so-called "Golden Verses") were apparently cited with approval by Epicurus, leading the hostile Heraclitus to dub him the "Phaeacian philosopher." 79 Philodemus elsewhere suggests that philosophy's ability to enchant the mind was greater than that of the Sirens, and this, too, was likely a reference to Epicurus, who may have compared the seductive lure of paideia to a Siren song. ${ }^{80}$

As a Greek philosopher prominent in Roman aristocratic circles of the first century B.C.E., Philodemus brings us closer to both the time and the culture of the Odyssey Landscapes. His reliance on Homer to impart lessons to Roman aristocrats shows that Homeric poetry continued not only to play a central role in philosophical conversation but also to function as a shared repository of culture and knowledge for these now Hellenized Romans. ${ }^{81}$ This is perhaps not the place to go into an extended account of the role that Homeric poetry played in late republican Rome, but there are a few examples directly relevant to the scenes depicted in the Odyssey Landscapes. Roughly contemporaneous with the painting is an often cited passage of Lucretius, who allegorizes the torments of Hades as representations of the torments of the soul. Tellingly, three of the four underworld myths depicted in the painting (fig. 2) are mentioned by

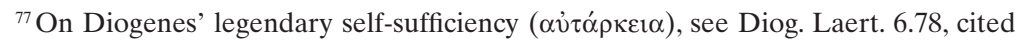
by Dudley 1937, 17 (see also 36-37). On the Cynic affinity for Odysseus, see Buffière 1956, 372-74. Höistad 1948, 94-101, reads the Odysseus by the proto-Cynic Antisthenes as a work of philosophy; Antisthenes also wrote a lost work "On Circe" (see Decleva Caizzi 1966, 84-85).

78 "Legendary" is perhaps the key word, since recent work on Epicurus disputes the extent to which he condemned poetry. For a useful survey, with bibliography, see Janko 2000, 9-10.

${ }^{79}$ Asmis 1995, 16-17. The reconstruction of Epicurus' exact use of the parallel is difficult, but the connection seems to have attracted some notoriety, which may lie behind Philodemus' promise to Piso that the conversation at his humble celebration of Epicurus' birthday will be "much sweeter than the land of the Phaeacians" (Anth. Pal.11.44 [= Phld.

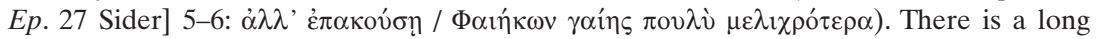
history of philosophical reaction to the Golden Verses, most famously Socrates' critical summary in the Republic (390a-b); see Kaiser 1964, 213-23.

${ }^{80}$ See Asmis 1995, 18. Philosophers (and others) frequently used the Sirens as a metaphor; see Kaiser 1964, 111-36.

${ }^{81}$ On the place of Homer in Roman culture, see Farrell 2004. 
Lucretius, including the Danaids, who do not make an appearance in the Homeric Odyssey. ${ }^{82}$ Seneca's dismissal of this type of allegory of Hades as "Epicurean poppycock" (Epicuream cantilenam, Ep. 24.18) suggests that it may have been an Epicurean topos used by other authors besides Lucretius; if so, we might expect an educated viewer of the painting to be familiar with the allegory.

A generation or two later Horace, another Roman poet with Epicurean allegiances, offers one of the more famous personal readings of the Iliad and the Odyssey. While his friend Lollius Maximus is busy in Rome, the poet is at leisure in Praeneste, culling philosophical lessons from Homer, for Homer tells us "more plainly and eloquently than Chrysippus and Crantor what is honorable and what is shameful, what is expedient and what is not." ${ }^{83} \mathrm{He}$ goes on to list possible things we might learn from the Iliad, stressing the bad behavior of men in wartime, who are motivated by "sedition, treachery, crime, passion, and rage" (15). By contrast, the Odyssey displays the usefulness of ethical behavior and philosophical wisdom in the face of personal challenges (Epist. 1.2.17-26):

rursus, quid virtus et quid sapientia possit, utile proposuit nobis exemplar Ulixen,

qui domitor Troiae multorum providus urbes et mores hominum inspexit latumque per aequor, dum sibi, dum sociis reditum parat, aspera multa pertulit, adversis rerum immersabilis undis.

Sirenum voces et Circae pocula nosti; quae si cum sociis stultus cupidusque bibisset, sub domina meretrice fuisset turpis et excors; vixisset canis immundus vel amica luto sus.

Or again, as a useful example of what virtue and wisdom can achieve, [Homer] has given us Odysseus, that tamer of Troy, a man of foresight, who examined the cities and behavior of many people; while arranging a homecoming for himself and his companions, he endured many hardships all over the broad sea, but he never sank in the challenging waves of life.

${ }^{82}$ Lucr. 3.978-1023 (Tityus: 984-94; Sisyphus 995-1002; "Danaids”: 1003-10). The Danaids are not in fact mentioned by name by Lucretius, and Lowenstam 1995, 208-18, points out that their appearance in the painting marks the first extant (explicit) conflation of the Danaid myth with the Pythagorean myth of the water carriers in Hades. On the history of the water-carrier myth, see Keuls 1974.

${ }^{83}$ Epist. 1.2.3-4: "qui, quid sit pulcrum, quid turpe, quid utile, quid non, / planius ac melius Chrysippo et Crantore dicit." On Horace's varied philosophical allegiances in his Epistles, see Mayer 1986. 
You're familiar with the songs of the Sirens and the potions of Circe. If he had been so stupid and greedy as to drink them along with his companions, he would have been the loathsome and unfeeling property of that whore mistress; he would have lived out his life as a mangy dog or as a muck-loving sow.

Horace replicates the metaphorical utility of Odysseus' actions for his contemporary readers by translating directly from his source; lines 19 to 22 recreate the first five lines of the Odyssey. Moreover, there is a second adaptation at play here, as Gigante has shown: despite the apparent Stoic flavor of Odysseus'virtus et sapientia, Horace depends upon Philodemus' On the Good King According to Homer for much of his argument here. ${ }^{84}$ The Epicurean intertext undercuts Horace's rejection of the philosophers Chrysippus and Crantor and renders his "everyman's" reading of Homer as somewhat ironic, in typical Horatian fashion.

Yet in this way, too, Horace's exegesis provides a useful parallel for the Odyssey Landscapes. Just as the reader can appreciate Horace's poem with or without the nuance of the reference to Philodemus, the viewer of the Odyssey Landscapes can approach a "philosophical" reading of the painting from multiple angles. As in Horace's poem, a basic knowledge of the stories of Circe and the Sirens is presumed by the painting (Sirenum voces et pocula Circae nosti ...), and conversation about the relevance of such myths to the daily lives of contemporary viewers can proceed whether or not they are familiar with specific philosophical allegories of these figures. ${ }^{85}$ In many ways, this would be true whether or not the portico frame were present; the ninth panel (fig. 2) would surely make recent readers of Lucretius think of his allegory of the torments of Hades, with or without the framing pillars. But what the portico frame suggests is that the walk of the viewer and the "walk" of Odysseus are somehow parallel and that both journeys will lead to the accumulation of knowledge. By depicting Odysseus traveling through a landscape, in a continuous narrative, the painter invites the viewer to travel along with the hero, in this imaginary portico, thereby learning what Odysseus learned during his travels.

${ }^{84}$ Gigante 1984, 296-98. For an extended study of the Philodemean influence on Horace's Epistles, see Armstrong 2004 (and 276-81 on Ep. 1.2 in particular).

${ }^{85}$ By way of comparison, the Odyssean sculptural program at Sperlonga has inspired a similar range of responses, with Odysseus either embodying Stoic virtues (Andreae $1974,105)$ or demonstrating an adaptability that resists simple philosophical allegiances (Stewart 1977, 78). 
Although we do not possess the entire painting, what we do have encourages a developmental reading of Odysseus' character as he passes along the wall of this late republican house..$^{86}$ If we take the Circe panel as the halfway point of our narrative, as the perspective of the columns demands that we do, we may notice a clear difference between the Odysseus of the first half and the Odysseus of the second half. The first half of the narrative is given over to the slaughter of the Greeks by the superhuman Laestrygonians. What is noticeable about this part of the story is that our hero is completely absent from the picture; as we observed earlier, Odysseus does not appear in the extant pictures until his ship escapes the monsters in the fifth section (plate 2), nor does he appear in his actual person but rather in an inscription. The first we see of the hero is his entrance into Circe's palace in the central panel (fig. 1). The absence of the hero from the Laestrygonian episode in many ways parallels the Homeric model in which Odysseus sends his men in to do the dirty work for him (Od.10.100-102). And while we could say that the narrative emphasizes his ingenuity, since he remembered to leave his ship outside the harbor whereas his men did not, we could not assess the Laestrygonian adventure as a successful episode for Odysseus given the loss of men and ships it entailed. Similarly, if the first panel did in fact depict his men setting free the winds while Odysseus slept ${ }^{87}$ the artist will have chosen another less-than-heroic episode in his travels; the release of the winds, though perhaps not directly the fault of Odysseus, is hardly a testimony to his virtus and sapientia. The overall pattern of the first half of the frieze, we might say, is Odysseus being controlled by his circumstances and not the other way around.

This pattern is precisely what makes the theme of the central panel (i.e., panel 6) so interesting (fig. 13). We have already seen that this panel is one of the more daring examples of continuous narrative, depicting as it does two successive scenes at the same moment, in the same frame, indeed, virtually side by side. The contrast is of course heightened by the framing colonnade, which has given every other scene its own internal coherence, as successive scenes in an ongoing narrative. But in panel 6,

\footnotetext{
${ }^{86}$ For a defense of the view that the notion of character development existed in ancient thought, see Gill 1983, and for the development of the Homeric Odysseus in particular, Rutherford 1986. More relevant to our discussion is Jeffrey Fish's recent reconstruction of column 36 of On the Good King According to Homer, in which Philodemus seems to argue that Odysseus underwent a philosophical "correction" in the Odyssey; see Fish 2004, 112-14. (I am grateful to Jeffrey Fish for his assistance on this matter.)

${ }^{87} \mathrm{~A}$ possibility suggested by the personified winds in the upper-left corner of the second panel (plate 1); see von Blanckenhagen 1963, 104.
} 
the device is broken in dramatic fashion, and we are forced by the narratological switch to linger here.Moreover, the perspective of the framing portico places the ideal viewer directly before this scene. The central panel is doubly jarring: as we have seen, the portico frame enforces a metaphor of ambulatory contemplation, yet its perspective also demands a stationary pose in front of this central panel. What is interesting for our study is that this breakdown occurs precisely at the point in the painting where Odysseus interrupts the pattern developed in the first half of the narrative; here we see Odysseus transformed from the controlled to the controller. When Odysseus is welcomed into Circe's palace, his men have already been turned into animals; although their metamorphosis is mostly a reflection of their own gullibility, the episode is not exactly a sterling endorsement of Odysseus' leadership. In the narrative gap, however, Odysseus has drunk the cup, but it has no effect on him, protected as he is by Hermes' moly. As he draws his sword, he reasserts his control over the narrative, which will remain to the end of our extant fragments. Indeed, in our last (fragmentary) panel (fig. 3), we can barely make out Odysseus, tied to the mast so that he may hear the Sirens without succumbing to their deadly charm. The episode is duly famous and easily moralized by later readers as the proper way to enjoy things without enjoying them too much. ${ }^{88}$ Horace, master of the aurea mediocritas, clearly reads it as such, and it is fitting for our analysis that the two scenes he singles out in Epist. 1.2 (Sirenum voces et Circae pocula, 23) are both depicted in the Odyssey Landscapes.

The ethical reading suggested above is just one possible philosophical reading of the episodes depicted and need not exclude other readings. ${ }^{89}$ This is the point of the portico frame: the metaphor of ambulatory philosophical contemplation that it imposes allows for individual reactions and personal interpretations and is thus meant to spur discussion among the strolling viewers. ${ }^{90}$ The portico frame of the Odyssey Landscapes played an essential role in the interpretation of the painting by acting as a

${ }^{88}$ See Buffière 1956, 380-86, and Kaiser 1964, 121-31.

${ }^{89}$ Lowenstam 1995, 213-14, for example, briefly entertains (and rejects) a Pythagorean reading of the Odyssey Landscapes.

${ }^{90}$ Bettina Bergmann has shown in a number of articles the various ways in which the arrangement of wall paintings at Pompeii evoke the Roman rhetorical practices endemic to Roman aristocratic thought and behavior; see Bergmann 1994 and Bergmann 1999, esp. p. 101: "It was in rethinking and arguing fundamental social issues of myths that Romans could articulate their own current problems. The strategies of that self-reflection, I believe, are comparable to the arrangements of myths in Roman rooms, where the abilities learned at school-to speak, listen, envision—became recreational pleasure." 
mediating device, an interpretive lens through which the Roman viewer was encouraged to see connections between the wanderings of Odysseus and the ambulatio of the Roman aristocrat. The painted portico refers not only to an architectural form but also to an entire culture that would have been intimately familiar to a viewer of that painting in the mid-first century B.C.E., bringing together associations of movement of the body, acquisition of knowledge, philosophical contemplation, mythology as exemplum, and travel. By combining an allusion to this culture with the fantasy world of mythological landscape, the artist has taken an aspect of the viewer's Lebenswelt and elevated it to the level of myth. ${ }^{91}$ Like Philodemus in his letter to Piso, this Roman homeowner promises his guests a strolling conversation as sweet as (or sweeter than) Odysseus' conversation with the Phaeacians. ${ }^{92}$

TRINITY UNIVERSITY

e-mail: tosulliv@trinity.edu

\section{BIBLIOGRAPHY}

Anderson, James C. 1997. Roman Architecture and Society. Baltimore: Johns Hopkins University Press.

Andreae, Bernard. 1962. "Der Zyklus der Odysseefresken im Vatikan.” $M D A I(R)$ 69:106-17.

- 1974. "Die römischen Repliken der mythologischen Skulpturengruppen von Sperlonga." In Die Skulpturen von Sperlonga: I gruppi scultorei di soggetto mitologico a Sperlonga, ed. Baldassare Conticello and Bernard Andreae, 61-105. Berlin: G. Mann.

- 1988. "Wandmalerei augusteischer Zeit." In Kaiser Augustus und die verlorene Republik: Eine Ausstellung im Martin-Gropius-Bau, Berlin, 7. Juni-14. August 1988, 273-90. Mainz: Philipp von Zabern.

\footnotetext{
${ }^{91}$ Kuttner 2003,112, makes the intriguing suggestion that the palace of Circe in panel 6 (fig. 13) evokes the aristocratic villa maritima.

${ }^{92}$ I first presented these ideas at a graduate conference at Columbia University ("House and Home in the Greco-Roman World") on 10 February 2001, and again as a talk to the classics department at UT Austin on 8 September 2005. I am grateful to both audiences for their feedback. I gratefully acknowledge the support of the Mellon Foundation's Robert F. Goheen Prize and Harvard University's Charles P. Segal Student Research and Travel Fund, which enabled me to see the Odyssey Landscapes; during my visit to the Vatican, Guido Cornini was a gracious host. The article has benefited from the readings of a number of colleagues, and I would like to thank Kathleen Coleman in particular, as well as Bettina Bergmann, Erwin Cook, Gloria Ferrari Pinney, Robert Germany, Thomas Jenkins, and Leah Kronenberg. I would also like to thank Barbara Gold and the two anonymous reviewers for $A J P$.
} 
Andronicos, Manolis. 1984. Vergina: The Royal Tombs and the Ancient City. Athens: Ekdotike Athenon S.A.

Armstrong, David. 2004. "Horace's Epistles 1 and Philodemus." In Vergil, Philodemus, and the Augustans, ed. David Armstrong et al., 267-98. Austin: University of Texas Press.

Asmis, Elizabeth. 1991. "Philodemus's Poetic Theory and On the Good King According to Homer." ClAnt 10:1-45.

- 1995. "Epicurean Poetics." In Philodemus and Poetry: Poetic Theory and Practice in Lucretius, Philodemus, and Horace, ed. Dirk Obbink, 15-34. Oxford: Oxford University Press.

Baldassarre, Ida, et al. 2002. Pittura romana: Dall'ellenismo al tardo antico. Milan: F. Motta.

Barbet, Alix. 1985. La peinture murale romaine: Les styles décoratifs pompéiens. Paris: Picard.

Beard, Mary, and John Henderson. 2001. Classical Art: From Greece to Rome. Oxford: Oxford University Press.

Beltrán Fortes, José. 1995. "La incorporación de los modelos griegos por las élites romanas en ámbito privado: Una aproximación arqueológica.” In Graecia capta: De la conquista de Grecia a la helenización de Roma, ed. Emma Falque Rey and Fernando Gascó, 201-32. Huelva: Universidad de Huelva.

Bergmann, Bettina. 1994. "The Roman House as Memory Theater: The House of the Tragic Poet at Pompeii." ABull 76:225-56.

. 1995. "Greek Masterpieces and Roman Recreative Fictions." HSCP 97:79-120.

- 1999. "Rhythms of Recognition: Mythological Encounters in Roman Landscape Painting." In Im Spiegel des Mythos: Bilderwelt und Lebenswelt = Lo specchio del mito: Immaginario e realtà, ed. Francesco de Angelis and Susanne Muth, 81-107. Wiesbaden: Ludwig Reichert Verlag. . 2001. "Meanwhile, Back in Italy . . . Creating Landscapes of Allusion." In Pausanias: Travel and Memory in Roman Greece, ed. Susan E. Alcock, John F. Cherry, and Jaś Elsner, 154-66. Oxford: Oxford University Press.

Beyen, Hendrik Gerard. 1960. Die pompejanische Wanddekoration vom zweiten bis zum vierten Stil. Vol. 2, pt. 1. The Hague: M. Nijhoff.

Biering, Ralf. 1995. Die Odysseefresken vom Esquilin. Munich: Biering und Brinkmann.

Braun, Emil. 1849. "Römische Ausgrabungen: Scenen aus dem Abenteuer der Lästrygonen." Archäologische Zeitung 7 (AA 2, Feb. 1849): 27-32.

Brilliant, Richard. 1984. Visual Narratives: Storytelling in Etruscan and Roman Art. Ithaca, N.Y.: Cornell University Press.

Bruno, Vincent J. 1969. “Antecedents of the Pompeian First Style.” AJA 73:30517.

Buffière, Félix. 1956. Les mythes d'Homère et la pensée grecque. Paris: Société d'Édition Les Belles Lettres.

Carettoni, Gianfilippo. 1983. "La decorazione pittorica della casa di Augusto sul Palatino.” $\operatorname{MDAI}(R)$ 90:373-419. 
Clarke, John R. 1991. The Houses of Roman Italy, 100 B.C.-A.D. 250: Ritual, Space, and Decoration. Berkeley and Los Angeles: University of California Press.

Coarelli, Filippo. 1998. "The Odyssey Frescos of the Via Graziosa: A Proposed Context." PBSR 66:21-37.

Cook, Erwin F. 1995. The Odyssey in Athens: Myths of Cultural Origins. Ithaca, N.Y.: Cornell University Press.

Coulton, J. J. 1976. The Architectural Development of the Greek Stoa. Oxford: Clarendon Press.

Decleva Caizzi, Fernanda, ed. 1966. Antisthenis fragmenta. Milan: Istituto editoriale cisalpino.

Delorme, Jean. 1960. Gymnasion: Étude sur les monuments consacrés à l'éducation en Grèce (des origines à l'Empire romain). Paris: Éditions E. De Boccard.

Dickmann, Jens-Arne. 1997. "The Peristyle and the Transformation of Domestic Space in Hellenistic Pompeii." In Domestic Space in the Roman World: Pompeii and Beyond, ed. Ray Laurence and Andrew Wallace-Hadrill, 121-36. Portsmouth, R.I.: JRA.

-1999. Domus frequentata: anspruchsvolles Wohnen im pompejanischen Stadthaus. Munich: Verlag Dr. Friedrich Pfeil.

Drerup, Heinrich. 1959. "Bildraum und Realraum in der römischen Architektur." $\operatorname{MDAI}(R)$ 66:147-74.

Dudley, Donald R.1937. A History of Cynicism: From Diogenes to the 6th Century A.D. London: Methuen.

Ehrhardt, Wolfgang. 1987. Stilgeschichtliche Untersuchungen an römischen Wandmalereien: von der späten Republik bis zur Zeit Neros. Mainz: Philipp von Zabern.

- 1991. "Bild und Ausblick in Wandbemalungen zweiten Stils." $A K$ 34: 28-65.

Engemann, Josef. 1967. Architekturdarstellungen des frühen zweiten Stils: Illusionistische römische Wandmalerei der ersten Phase und ihre Vorbilder in der realen Architektur. Heidelberg: F.H. Kerle.

Farrell, Joseph. 2004. "Roman Homer." In The Cambridge Companion to Homer, ed. Robert Fowler, 254-71. Cambridge: Cambridge University Press.

Fish, Jeffrey. 2004. "Anger, Philodemus' Good King, and the Helen Episode of Aeneid 2.567-89: A New Proof of Authenticity from Herculaneum." In Vergil, Philodemus, and the Augustans, ed. David Armstrong et al., 111-38. Austin: University of Texas Press.

Fisher, Nick. 1998. "Gymnasia and the Democratic Values of Leisure." In Kosmos: Essays in Order, Conflict, and Community in Classical Athens, ed. Paul Cartledge, Paul Millett, and Sitta von Reden, 84-104. Cambridge: Cambridge University Press.

Ford, Andrew. 1999. "Performing Interpretation: Early Allegorical Exegesis of Homer." In Epic Traditions in the Contemporary World: The Poetics of Community, ed. Margaret H. Beissinger, Jane Tylus, and Susanne Lindgren Wofford, 33-53. Berkeley and Los Angeles: University of California Press. 
Gazda, Elaine K. 1995. "Roman Sculpture and the Ethos of Emulation: Reconsidering Repetition." HSCP 97:121-56.

-, ed. 2002. The Ancient Art of Emulation: Studies in Artistic Originality and Tradition from the Present to Classical Antiquity. Ann Arbor: University of Michigan Press.

Gigante, Marcello. 1984. "Per l'interpretazione del libro di Filodemo Del buon re secondo Omero." PP 217:285-98.

Gill, Christopher. 1983. "The Question of Character-Development: Plutarch and Tacitus." CQ 33:469-87.

Ginouvès, René. 1992. Dictionnaire méthodique de l'architecture grecque et romaine. Vol. 2, Élements constructifs: Supports, couvertures, aménagements intérieurs. Rome: École française d'Athènes / École française de Rome.

Gleason, Kathryn L. 1990. "The Garden Portico of Pompey the Great: An Ancient Public Park Preserved in the Layers of Rome." Expedition 32.2:4-13.

Görler, Woldemar. 1988. "From Athens to Tusculum: Gleaning the Background of Cicero's De oratore." Rhetorica 6:215-35.

. 1990. "Syracusae auf dem Palatin; Syracuse, New York: Sentimentale Namengebung in Rom und später." In Pratum Saraviense: Festgabe für Peter Steinmetz, ed. Woldemar Görler and Severin Koster, 169-88. Stuttgart: F. Steiner.

Grahame, Mark. 1997. "Public and Private in the Roman House: The Spatial Order of the Casa del Fauno." In Domestic Space in the Roman World: Pompeii and Beyond, ed. Ray Laurence and Andrew Wallace-Hadrill, 137-64. Portsmouth, R.I.: JRA.

Hardie, Philip R. 1986. Virgil's Aeneid: Cosmos and Imperium. Oxford: Oxford University Press.

Hartog, Francois. 2001. Memories of Odysseus: Frontier Tales from Ancient Greece. Trans. Janet Lloyd. Chicago, Ill.: University of Chicago Press.

Henzen, Wilhelm. 1850. "Römische Ausgrabungen." Archäologische Zeitung 8 (AA 15, Feb. 1850):165-68.

Höistad, Ragnar. 1948. Cynic Hero and Cynic King: Studies in the Cynic Conception of Man. Uppsala: [B.H. Blackwell].

Holliday, Peter James. 2002. The Origins of Roman Historical Commemoration in the Visual Arts. Cambridge: Cambridge University Press.

Janko, Richard, ed. 2000. Philodemus: On Poems, Book 1. With intro., trans., and comm. Oxford: Oxford University Press.

Jashemski, Wilhelmina. 1979. The Gardens of Pompeii, Herculaneum and the Villas Destroyed by Vesuvius. New Rochelle, N.Y.: Caratzas Brothers.

Kaiser, Erich. 1964. "Odyssee-Szenen als Topoi.” MH 21:109-36, 197-224.

Keuls, Eva C. 1974. The Water Carriers in Hades: A Study of Catharsis through Toil in Classical Antiquity. Amsterdam: A.M. Hakkert.

Kuttner, Ann. 1995. "Republican Rome Looks at Pergamon.” HSCP 97:157-78. 1999. "Culture and History at Pompey's Museum." TAPhA 129:343-73. 2003. "Delight and Danger in the Roman Water Garden: Sperlonga and 
Tivoli." In Landscape Design and the Experience of Motion, ed. Michel Conan, 103-56. Washington, D.C.: Dumbarton Oaks.

Lamberton, Robert, and John J. Keaney, eds. 1992. Homer's Ancient Readers: The

Hermeneutics of Greek Epic's Earliest Exegetes. Princeton, N.J.: Princeton University Press.

Leach, Eleanor Winsor. 1981. "Metamorphoses of the Acteon Myth in Campanian Painting." $M D A I(R)$ 88:307-27.

. 1986. "The Punishment of Dirce. A Newly Discovered Painting in the Casa di Giulio Polibio and Its Significance within the Visual Tradition." $M D A I(R)$ 93:157-82.

. 1988. The Rhetoric of Space: Literary and Artistic Representations of Landscape in Republican and Augustan Rome. Princeton, N.J.: Princeton University Press.

- 1997. "Oecus on Ibycus: Investigating the Vocabulary of the Roman House." In Sequence and Space in Pompeii, ed. Sara E. Bon and Rick Jones, 50-72. Oxford: Oxbow Books.

- 2004. The Social Life of Painting in Ancient Rome and on the Bay of Naples. Cambridge: Cambridge University Press.

Ling, Roger. 1977. "Studius and the Beginnings of Roman Landscape Painting." JRS 67:1-16.

- 1991. Roman Painting. Cambridge: Cambridge University Press.

Lowenstam, Steven. 1995. "The Sources of the Odyssey Landscapes." EMC 39 (n.s. 14):193-226.

Lydakis, Stelios. 2004. Ancient Greek Painting and Its Echoes in Later Greek Art. Los Angeles: Getty Publications.

MacDonald, William Lloyd. 1986. The Architecture of the Roman Empire. Vol. 2, An Urban Appraisal. Rev. ed. New Haven, Conn.: Yale University Press.

MacDonald, William Lloyd, and John A. Pinto. 1995. Hadrian's Villa and Its Legacy. New Haven, Conn.: Yale University Press.

Maiuri, Amedeo. 1946. "Portico e Peristilio." PP 3:306-22.

Matranga, Pietro. 1852. La città di Lamo stabilita in Terracina secondo la descrizione di Omero e due degli antichi dipinti già ritrovati sull'Esquilino. Rome: Tipografia della reverenda Camera Apostolica.

Mayer, Roland. 1986. "Horace's Epistles I and Philosophy." AJPh 107:55-73.

Mielsch, Harald. 1987. Die römische Villa: Architektur und Lebensform. Munich: C.H. Beck.

- 2001. Römische Wandmalerei. Stuttgart: Theiss.

Montiglio, Silvia. 2005. Wandering in Ancient Greek Culture. Chicago: University of Chicago Press.

Nagy, Gregory. 1979. The Best of the Achaeans: Concepts of the Hero in Archaic Greek Poetry. Baltimore: Johns Hopkins University Press.

Neudecker, Richard. 1988. Die Skulpturenausstattung römischer Villen in Italien. Mainz: Philipp von Zabern.

Nightingale, Andrea Wilson. 2004. Spectacles of Truth in Classical Greek Philoso- 
phy: Theoria in Its Cultural Context. Cambridge: Cambridge University Press.

O’Sullivan, Timothy M. 2006. "The Mind in Motion: Walking and Metaphorical Travel in the Roman Villa." CPh 101:133-52.

Osborne, Robin. 1987. "The Viewing and Obscuring of the Parthenon Frieze." JHS 107:98-105.

Parslow, Christopher Charles. 1989. “The Praedia Iuliae Felicis in Pompeii.” Ph.D. diss., Duke University.

Pollitt, J. J. 1986. Art in the Hellenistic Age. Cambridge: Cambridge University Press.

Pugliese Carratelli, Giovanni, ed. 1990-2003. Pompei: Pitture e mosaici, 10 vols. Rome: Istituto della enciclopedia italiana.

Richardson, Lawrence, Jr. 1977. "Hercules Musarum and the Porticus Philippi in Rome.” AJA 81:355-61.

—.1992. A New Topographical Dictionary of Ancient Rome. Baltimore: Johns Hopkins University Press.

Robert, Carl. 1881. Bild und Lied: Archäologische Beiträge zur Geschichte der griechischen Heldensage. Berlin: Weidmann.

Robertson, Martin. 1955. "The Boscoreale Figure-Paintings." JRS 45:58-67.

Rutherford, R. B. 1986. "The Philosophy of the Odyssey." JHS 106:145-62.

Scagliarini Corlàita, Daniela. 1974-76. "Spazio e decorazione nella pittura pompeiana." Palladio 23-25:3-44.

.1997. "Propter spatia longitudinis: Cicli e serie figurative nelle ambulationes del secondo e del quarto 'stile pompeiano'." In I temi figurativi nella pittura parietale antica (IV sec. a.C.-IV sec. d.C.): Atti del VI Convegno Internazionale sulla Pittura Parietale Antica, ed. Daniela Scagliarini Corlàita, 119-23. Imola: University Press Bologna.

Senseney, John Robert. 2002. "The Shaping of Imperial Order: Rome's Porticoed Enclosures from the Late Republic to the High Principate and the Question of Hellenistic Antecedents." Ph.D. diss., University of California, Santa Barbara.

Small, Jocelyn Penny. 1999. "Time in Space: Narrative in Classical Art." ABull 81:562-75.

Stanford, W. B. 1963. The Ulysses Theme: A Study in the Adaptability of a Traditional Hero. 2d ed. Oxford: Blackwell.

Stansbury-O'Donnell, Mark. 1999. Pictorial Narrative in Ancient Greek Art. Cambridge: Cambridge University Press.

Stewart, Andrew. 1977. "To Entertain an Emperor: Sperlonga, Laokoon and Tiberius at the Dinner-Table." JRS 67:76-90. - 1996. “A Hero's Quest: Narrative and the Telephos Frieze.” In Pergamon: The Telephos Frieze from the Great Altar. Vol. 1, ed. Renée Dreyfus and Ellen Schraudolph, 39-52. San Francisco, Calif.: Fine Arts Museums of San Francisco. 
Strocka, Volker Michael. 1991. Casa del Labirinto: (VI 11,8-10). Munich: Hirmer Verlag.

Thomas, Eberhard. 1995. "Zum Zeugniswert griechischer Beischriften auf römischen Wandgemälden der späten Republik und frühen Kaiserzeit." MNIR 54:110-23.

Tybout, Rolf A. 1989. Aedificiorum figurae: Untersuchungen zu den Architekturdarstellungen des frühen zweiten Stils. Amsterdam: J.C. Gieben. . 2001. "Roman Wall-painting and Social Significance." JRA 14:33-56.

Vlad Borrelli, Licia. 1956. "Un nuovo frammento dei 'paesaggi dell'Odissea'." BA 41:289-300.

von Blanckenhagen, Peter H. 1957. "Narration in Hellenistic and Roman Art." AJA 61:78-83. . 1963. "The Odyssey Frieze.” MDAI(R) 70:100-146.

Wallace-Hadrill, Andrew. 1994. Houses and Society in Pompeii and Herculaneum. Princeton, N.J.: Princeton University Press. - 1997. "Rethinking the Roman Atrium House." In Domestic Space in the Roman World: Pompeii and Beyond, ed. Ray Laurence and Andrew Wallace-Hadrill, 219-40. Portsmouth, R.I.: JRA. - 1998. "To Be Roman, Go Greek: Thoughts on Hellenization at Rome." In Modus operandi: Essays in Honour of Geoffrey Rickman, ed. Michel Austin, Jill Harries, and Christopher John Smith, 79-91. London: Institute of Classical Studies, School of Advanced Study, University of London.

Zanker, Graham. 2004. Modes of Viewing in Hellenistic Poetry and Art. Madison: University of Wisconsin Press.

Zanker, Paul. 1988. The Power of Images in the Age of Augustus. Trans. Alan Shapiro. Ann Arbor: University of Michigan Press. . 1998. Pompeii: Public and Private Life. Trans. Deborah Lucas Schneider. Cambridge, Mass.: Harvard University Press. 